線学的変化について, 中部日本整災会誌. 11 : 781 , 昭 43 .

2) 恩地 裕 - 他: Cervical disorders の診断之 治療, 整形外科. $15: 297$, 昭39.

3）近藤鋭矢・他：頸部脊椎骨軟骨症，日整会誌. $35: 755,1961$.

4) 柏木大治 - 他：Cloward 法頸椎前方固定術の 要点, 手術. XXI : 10, 1031, 1967.

5）服部 奖：頸部脊椎骨軟骨症の観血的療法につ いて，整形之災害， $17: 7$ ，昭 42 .

6) 森健躬：前方進入路に上る頸椎椎体固定術, 手術. XIX : 5, 363, 1965.

7）鶴海寛治 - 他：頸部脊椎骨軟骨症の手術成樍, 日外宝. 31，72，昭35.
8）鶴海寛治：頸部脊椎骨軟骨症の脊㗓症状と診 断, 整形外科. $13: 898$, 昭36.

追加 質問 山口大学 服部 奨

御報告の結果はわれわれの経験でも，同じ攧向をみ とめている．抄録に悪化 2 例とあつたがその内容は。

回答演者

悪化および不変例 2 例については， 1 例は糖尿病性 神経を併発したものであり，他の1例は不変と認めた ものである。

\title{
当教室の頸、肩、腕症候群患者の統計的観察
}

\begin{tabular}{|c|c|c|c|c|c|c|}
\hline 平 & 由 & 真 & 也 & 服 & 部 & \\
\hline 山 & 本 & 一 & 男 & 小 & 田 & 清 \\
\hline 守 & 田 & 利 & 彦 & 松 & 井 & \\
\hline 後 & 藤 & $\longrightarrow$ & 成 & 菏 & 野 & \\
\hline 岩 & 永 & & 寛 & 河 & 合 & 伸 \\
\hline 開 & 地 & 逸 & 朗 & 東 & & 良 \\
\hline
\end{tabular}

\section{Statistical Studies on the Patient of Cervico-omo-brachial Syndrome in Our Clinic}

By

\author{
S. Hirata, S. Hattori, K. Yamamoto, K. Oda, \\ T. Morita, S. Matsui, K. Goto, K. Kawano, \\ K. Iwanaga, S. Kawai, I Kaichi, \& Y. Azuma \\ Department of Orthopedic Surgery, Yamaguchi University \\ School of Medicine
}

In the last 8 years, 1407 patients were diagnosed as cervico-omo-brachial syndrome in our out-patient clinic. We could classify the various disorders considered as a cause of the cervico-omo-brachial syndrome on the basis of the clinical findings, plain and functional radiograms.

In these disorders, there are cervical osteochondrosis (subdivided into radicular syndrome and spinal cord compression groups), scalenus anticus syndrome, cervical rib, costo-clavicular syndrome, hyperabduction syndrome, Pancoast tumor and tumors in the cervical spine etc. But in the cases of undetermined cause we classified them as other.

342 of 435 patients of cervico-omo-brachial syndrome were of radicular syndrome $(79 \%)$ and 93 of them of spinal cord compression groups (31\%). Others were 922 cases (67\%). 
We discussed each group according to age, sex, occupation, cause, sign and symptoms with their localization, radiological findings and end results.

過去 8 年間に当科外来を受診した頸局腕症候群を呈 する患者につき, 外来部察のため, 敨密な分類を行な いがたいが，臨床所見と笚純レ線および機能撮影など に上り, 颈部脊椎骨軟骨症, 斜角筋症候群, 頸助症候 群, 肋鎖症候群, 過外転症候群, Pancoast 腯焬など, 澒局腕痛の発生原因を比較的明らかになしえたもの と，成因の不明なものを「その他の頸肩腕痛」として 分類した. 更に領部脊椎骨軟骨症を根症状例, 脊㕼症 状例とに分け，その他の頸肩腕痛患者とともにそれぞ れ, 臨床所見, レ線所見および予後などにつき統計的 検討を加えたので報告する。

調查対象は昭和 35 年 1 月より, 同 43 年 8 月までの 8 年間に当科外来を訪れた项局腕症候群患者 1407 例 で, その内訳をみると, 頸部脊椎骨軟骨症 435 例〔根 症状例 342 例 (79\%), 脊㗙症状例 93 例 (21\%) と根 症状例が多い], 斜角筋症候群 30 例, 頙助症候群 5 例, 肋骨鎖骨症候群 5 例, 過外転症候群 3 例, 手根管

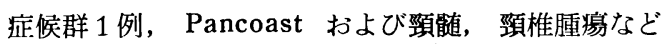
6 例, その他の頸肩腕痛は 922 例 (66 \%) にみとめ最 も多数をしめている.

表 1 頸・有・腕症候群患者の内訳 （S.35年 1 月〜S. 43 年 8 月）

\begin{tabular}{|c|c|c|}
\hline 類 & 例 & $\%$ \\
\hline 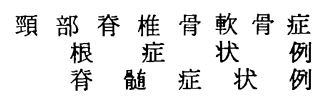 & $\begin{array}{c}435 \\
342(79 \%) \\
93(21 \%)\end{array}$ & 31 \\
\hline 斜 角 笳 症 候 群 & 30 & 2 \\
\hline $\begin{array}{l}\text { 頸 } \\
\text { 肋 骨 銷骨症 候 群 } \\
\text { 過 外転 症 候 群 } \\
\text { 手 根 管 症 候 群 } \\
\text { Pancoast, 頸髄, 頸椎腫瘍 }\end{array}$ & $\begin{array}{l}5 \\
5 \\
3 \\
1 \\
6\end{array}$ & 1 \\
\hline その他の頸肩腕 痛 & 922 & 66 \\
\hline 計 & 1,407 & 100 \\
\hline
\end{tabular}

次に各症候群別にそれぞれの臨床所見を統計的に検 討するに次の如き結果をえた。

\section{1）頸部脊椎骨軟骨症の根症状例}

40～50才に好発し，男性にやや多く，平均年令は 52 才で発症誘因をみとめるものは 342 例中 43 例 (12\%)
で比較的少なく，発症より来院時までの期間は 6 力月 以内が約半数をしぬ，患側別にみると両侧約 $40 \%$, 右側 $35 \%$, 左側 $25 \%$ \%右側に多くみとめ, また職業 別では事務 $(25 \%)$ ，無職 $(20 \%)$ 亿多くまた重労働 は $15 \%$ \%みとめられる。

自覚的症状として, 頸肩の限局痛が $(60 \%)$ と最も 多く，次いでしびれ感 $(48 \%)$ 放散痛 $(38 \%)$ の順で あり，また限局痛の発現部位は頸肩が多く，上肢がて れにつぐ．またしびれ感の発現部位は手指のみの例が 多く, 次に上腕から手指にかけて多くみとめる. 放散 痛の部位では手指まで放散する症例が最も多く見られ る . 压痛は腕神経叢部 (33\%), 僧帽筋 $(20.5 \%)$ 飞 多くみられる。次に筋萎縮は $18 \%$ にみとめられ, 上 肢での筋萎縮の部位は一定しない。

知覚障害については根症状例 342 例中 108 例 $30 \%$ にみとめ, その発現部位については, 上肢のみではあ るが, 未梢側ほど発現率が高く, 特に手指および前腕 に多く認められる。

指の巧絤運動障害は 51 例（15\%）にみとめ, 脊置 症状例にくらべ，かなり低率である。

頸椎の運動制限は 65 例（21\%）にみとめ, 前屈, 後屈時にやや多く障害をみとめる傾向必济ある。

圧痛は腕神経叢部 (33\%) 飞多く, ついで, 僧帽 筋, 斜角筋下部の順にみとめられる.

反射についてみると，上腕二頭筋の患側減弱が 28 例 (8\%), 岇進 20 例 (6\%) である.

次に Spurling's neck compression test 陽性例 は 87 例 $(25 \%)$, 腕神経叢の tension sign 83 例 (23 $\%$ ), Eaton's test 28 例 $(8.5 \%)$ にみとめられる.

単純レ線所見については, 椎間板狭小 $(58 \%)$, 後 棘形成 $(51 \%)$, 椎間孔狭小 (57\%) にみとめ, 銁椎 絬合部の変化 $(35 \%)$, 異常彎曲は 94 例 $(28 \%)$ 飞 みとめるが，乙れは脊剈有症状例の陽性率 $(16 \%)$ より やや高率である。

\section{2）頸部脊椎骨軟骨症の脊能症状例}

頸肩腕症候群患者全例の $21 \%$ をしめ, 好発年令は， 根症状例に比しやや高年者に多くみられ，平均年令は 55 才で，また患側別では両側例が $60 \%$ と根症状例の $40 \%$ より多くみとめられ, 左右差はほとんどない。職 
業別には事務 $(25 \%)$, 重学働 (26\%), 軽作業 (13 $\%)$, 無職 (11\%) が大部分である.

脊邻有症状例の自覚症状は, 根症状例にて, 最も多く みとめられた 頸局部の 限局痛よりもむしろしびれ感 （93\%）や手指の運動障㕩（55\%)を高率にみとめる， しびれ感の発現部位は, 両上下肢に同時にみとめられ る症例が最も多く，また四肢末梢部はど発現率が高い てとは注目して良い点と考えられる。

また知覚障邫は, 両.上下肢同時にみとめる症例が多 く, 次いで下肢のみ, 上肢のみの順にみとめる, 障害 部位は上下肢とも末梢側に多くみとめる症例が多い傾 向にある。

次に筋菱縮は上肢に多く，また下肢にも(10\%) み とめられる. 指の吅緻運動障害は $51 \%$ と高率にみと められ，また歩行障害も(52\%)と多くみとめられる 傾向にある。

さらに下肢の反射はずへて克進し，バビンスキー， クローヌスの陽性例もみられるが，Spurling's neck compression test, 腕神経叢の tension sign, Eaton's test の陽性率は低い傾向にある.

レ線所見では椎間枢狭小 $(55 \%)$, 異常彎曲(16\%) を認め, そのほか前棘, 後棘形成, 銁椎結合部の変化 などをみとめたが, 同年代の健常人と大差をみない。

\section{3）その他の頸肩腕痛}

その他の頸肩腕痛の症例は 922 例 $(66 \%$ ）をしめ, 平均年令は 39.2 才と比較的に若い年代に多くみとめ られ，患側別では両側例 $40 \%$ で，また左右差はなく， 職業別にみれば事務 $(24 \%)$, 無職 $(26 \%)$, 軽作業 (15\%) 飞多くみとめられ，自覚症状としては，限局 性の疼痛が 69 \%にみとめられ, 最も多く, その発現 部位は頸部, 肩部, 上肢全体の順に多くみとめられ, 疼痛が主症状であるととを示している。手指の巧絰運 動障害をみとめる例は（4\%）とすくなく，圧痛は腕 神経叢部 $29 \%$, 僧帽筋 $27 \%$ など比較的多くみとめ られる,なお脊鹃症状例に比較して腕神経叢部の圧痛 は低率で, てれに反し, 僧帽筋, 棘突起部, 腋窝神経 の圧痛が相対的にやや高率にみられる。また放散痛 や, 筋萎縮, 知覚障害はでくわずかにみとわられるに すぎず，また巧緱運動障害，握力の低下をみたものは でく少数にすぎなかつた。

レ線所見では椎間板狭小が $10 \%$, 異常彎曲が $22 \%$ に認められた。しかし異常彎曲については正常人にお
いても撮影時の下顎の高さにより異常彎曲をきたす場 合も起てりうるので, すべてにおいて病的所見とはみ なしがたい，疑わしい時は機能的レ線単純撮影を行な うのがよいと思う。

次に治療についてみれば，アンケートによる外来患 者の予後調査の結果から頸部脊椎骨軟骨症の根症状例 では $68 \%$ に，また「その他の頸局腕痛」の患者では $73 \%$ 亿, 症状の好転をみとめ, 約 $30 \%$ 前後の患者が 不変または覀化をきたしているてとが判明した。

保存的療法を継続するも，改善をみず，また再発悪 化を繰り返す症例には, 観血的療法の施行が適応とな る.なお手術成績については, 第 33 回, 本学会で報 告しましたので, 今回はその詳細とついての検討は省 略する。

以上, わたくしたちは, 増加の傾向にある頜肩腕症 候群患者の実態を把握するために，本症候群の外来患 者を対象として調查を企図したのであるが，外来腎者 を対象々した調查であるため, 病状の記載不十分なた めや, 予後調查に関してもアンケート形式によつたも のが多いため, 正確さの点で欠くるとてろもあると思 われるが，大体の傾向が 把握できたものと考劣てい る.

その結果は, とくに目新しいととも少ないけれぞ も, 若干興味ある知見も光られたので, 主な点を要約 すると次の如くである.すなわち

1) 外来診察のスクリーニングで, 成因を推定しえた 疾患としては, 頸部脊椎骨軟骨症が最も多く, 全体の 約 $31 \%$ をめ, そのうち根症状例が 春能症状例より 多い, 次いで前斜角筋症候群, 项肋など胞神経叢部障 害に属するものであるが, それらの頻度ははるかに低 率である.

2 ）外来診祭のスクリーニングでは成因不明の患者 が極めて多く, 全体の $66 \%$ をしめ, それらは概して 若い年代（平均 30 才代）に属している. それらの多 くは余り積極的治療もうけてはいないが, 予後調查の 結果によれば 7 割か洳転しており，3割が不変かつ悪 化を示している.てのととは本症候群の治療上に示唆 を与えるのみならず, 本症候群の成因解明の困難さを 痛感するとともに，その成因究明と治療に関しても今 後の研究にまつとてろが大きいととを再認識した。

\section{文献}

1）安藤啓三：日外宝函. $28: 3157$, 昭 34 . 
2）後藤一成・他：整形外科と災害外科. $17: 156$, 昭 43 .

3）服部 䍒 : 臨床整形外科全書. 4 巻, 第 1 版, 79 , 金原出版, 昭39.

4) 服部 奚 : 整形外科と災害外科. $17: 7$, 昭 42 .

5）飯野三郎：日医師会誌. $34: 305$, 昭 32 .

6）岩原寅猪 - 他：治療. $38: 118$, 昭30.

7）河邨文一郎：日本外科全書. 28巻, 第 1 版, 金 原出版, 昭30.

8) 近藤鋭矢: 日整会誌. $31: 1008$, 昭32.

9）近藤鋭矢・他: 日整会誌. $35: 755$, 昭36.

10）近藤鋭矢・他：手術. $17: 11$, 昭38.

11) 近藤鋭矢: 中部整災誌. $6: 833$, 昭39.

12) 西辻知生: 中部整災誌. $6: 890$, 昭39.

13）小野村敏信 - 他：臨床整形外科. $1: 143$, 昭41

14）大谷碧・他：日整会誌。 $41: 489$, 昭 42 .

15) 高岸直人：臨床整形外科. $1: 123$, 昭 41 .

16）都留美都雄: 臨床整形外科. $1: 131$, 昭 41 .

17) Adson, A. W. : Ann. Surg., 85 : 839, 1927.

18) Eaton, L. M. : Surg. Clin. N. Amer., 26 : 810, 1946.

19) Falconer, M. A. : New Zealand. Med. J., $49: 356,1950$.

20) Jackson, R. : The Cervical Syndrome, Charles C. Thomas, U. S. A., 3rd. Edition, 1966.

21) Semmes, R. E. : J. A. M. A., 121 : 1209, 1943.
22) Spurling, R. G.: Surg. Gynec. Obstet., : 78 350, 1944.

23) Smith, G. W. : J. B. J. S., 40-A : 607, 1958.

発言 九大整形 竹光 義治

最近つづけて電話交換手に本症を経験した。よく調 べてみると 104, 105 の係で肩の高さにある棚から重 い電話帳をとつており，乙れが原因かと思われた。乙 れらの例は Morley の圧痛点が゙+て証明され，前斜角 筋症候群が疑われた。

\section{質問熊大整形 広田 耕三}

電話交換手に澒肩腕症候群を訴える者が多いと云わ れているが，熊大の調查では特にそのような傾向は見 られない，先生の統計で職業別にみて電話父換手:に多 いと云う事実があつたか.

回答演者 特に電話交換手についてのみ限定して統計的検討を 加えてはいないが, 重労働者のみならず, キーパンチ ャ一，電話交換手等の軽作業者にも多くみとめられ る.

\title{
腰痛带装着に関する実態調査
}

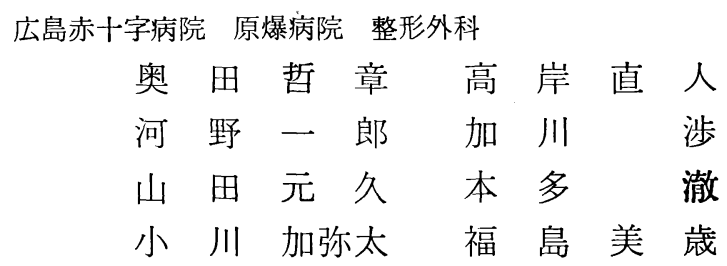

\section{Follow-up Studies of the Patients with Low Back Pain treated by Lumbago-band}

By

\author{
T. Okuda, N. Takagishi, I. Kouno, W. Kaga, \\ M. Yamada, T. Honda K. Ogawa \& M. Fukushima \\ Hiroshima Red Cross \& Atomic Bomb Hospital \\ Orthopaedic Surgery
}

For a means of the therapy of low back pain, the lumbagoband is prescribed.

During the past two years (1966-1967), 456 patients with low back pain were treated by 